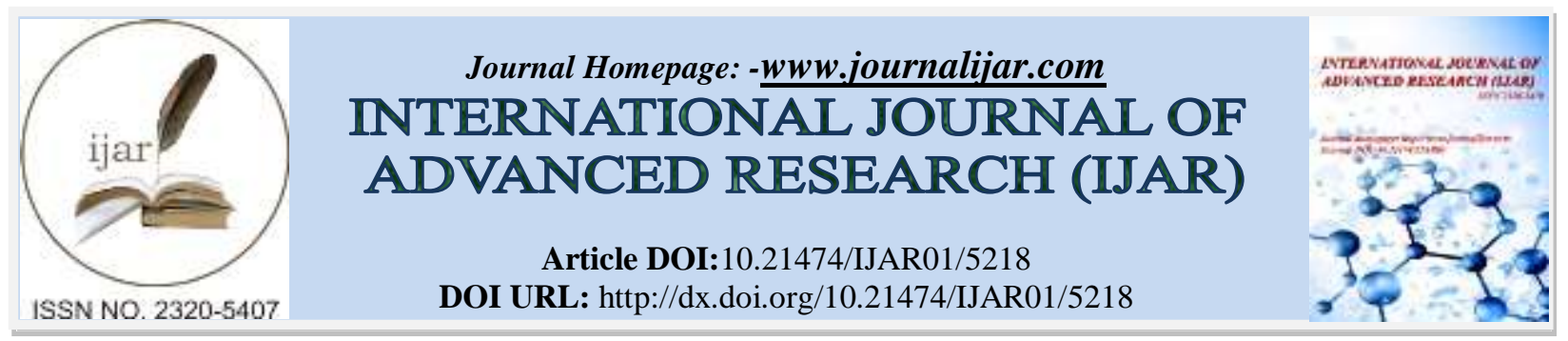

RESEARCH ARTICLE

\title{
DOUBLING THE INCOME OF SUGARCANE FARMERS WITH REDUCED COST IN INDIA AND CANE SCENARIO IN MAJOR SUGARCANE GROWING COUNTRIES.
}

\author{
ShriPrakash Yadav ${ }^{1}$ and Sonia Yadav ${ }^{2}$. \\ 1. Scientific officer (Agronomy) ) Sugarcane Research Institute,U.P. Council of Sugarcane Research \\ Shahjahanpur, (U.P)-242001. \\ 2. Scientific officer (Seed Production) Sugarcane Research Institute,U.P. Council of Sugarcane Research \\ Shahjahanpur ,(U.P)-242001.
}

\section{Manuscript Inf \\ Manuscript History}

Received: 19 June 2017

Final Accepted: 21 July 2017

Published: August 2017

\section{Abstract}

For the improvement of sugarcane in North India, a Sugarcane Research Station was established at Shahjahanpur in 1912 with simultaneous establishment of Sugarcane Breeding Centre at Coimbatore (Tamil Nadu). Sugarcane research work was conducted from 1907 to 1912 at Pratapgrah farm and from 1912 onward at Shahjahanpur by Mr. George Clarke F.I.C. the then Agricultural chemist of united provinces and later Director of Agriculture, U.P. Mr. H.R.C. Hailey I.C.S., Director of Agriculture and land records of U.P. made efforts to establish this station at Shahjahanpur. From 1918-2016 the U.P. Council of Sugarcane Research, Shahjahanpur has been released more than 200 varieties for sugarcane cultivation in U.P. At present 54 varieties are approved for cultivation on farmer's field. The U.P. series varieties have been developed by U.P. Council of Sugarcane Research, Shahjahanpur alone CoS (Coimbatore + Shahjahanpur) and CoSe (Coimbatore + Seorahi) series varieties have been developed by U.P. Council of Sugarcane Research, Shahjahanpur with the support of S.B.I., Coimbatore.

\section{Introduction}

In northern region as well as in India sugarcane is a major commercial crop that sustains sugar industry, the second largest next to cotton and textiles industries. India occupies better position in the world in area and production after Brazil but the cane yield /ha is generally lower, than several other countries like Peru, Australia, Brazil etc. Uttar Pradesh ranks first in the country with regards to cane area and also in sugar production in the country. Therefore the northern states role in improving national sugar productivity is obvious. Now days lower crop yields and decline in the factor productivity have raised a question mark over sustainability of crop yield level reached during green revolution period. While the use of mineral fertilizer is the quickest and surest way of boosting crop production, their cost and other constraints frequently deter farmers for using them in recommended quantities and in balanced proportion.

\section{Sugarcane scenario at a glance:-}

Worldwide sugarcane is main source of sugar. Sugarcane and sugar beet are grown for sugar globally. In the whole world $80 \%$ sugar is produced from sugarcane and 20\% from sugar beet. Sugarcane is grown in 123 countries on an about 24 million ha land but the largest area in Brazil (10.44 million ha). Highest productivity of cane is in Peru (about $133 \mathrm{t} / \mathrm{ha}$ ) followed by Ethiopia (about 119.57). in India, sugarcane Grown in about 5 million ha land with the average productivity (71 t/ha). In India, Uttar Pradesh ranks first in area $(2.19$ million ha) and also in sugar 
production (about 86 lakh tons) but productivity of U.P. is $72.37 \mathrm{t} / \mathrm{ha}$. The sugar recovery of the nation is about $10.50 \%$ but in U.P. sugar recovery is about 10.61 percent. The highest cane productivity is in Tamil Nadu (105.00 t/ha) followed by Karnataka (90.30 t/ha) and Maharashtra (80.90 t/ha). In southern region productivity is higher because climate is favourable for sugarcane growth and sugar recovery. Adsali and eksali crops are grown in southern states. For more productivity adsali crop is more responsible because it is planted during July - August and after 16-18 months harvested during November - December. Also the best time and temperature for ratoon to start is in December - January.

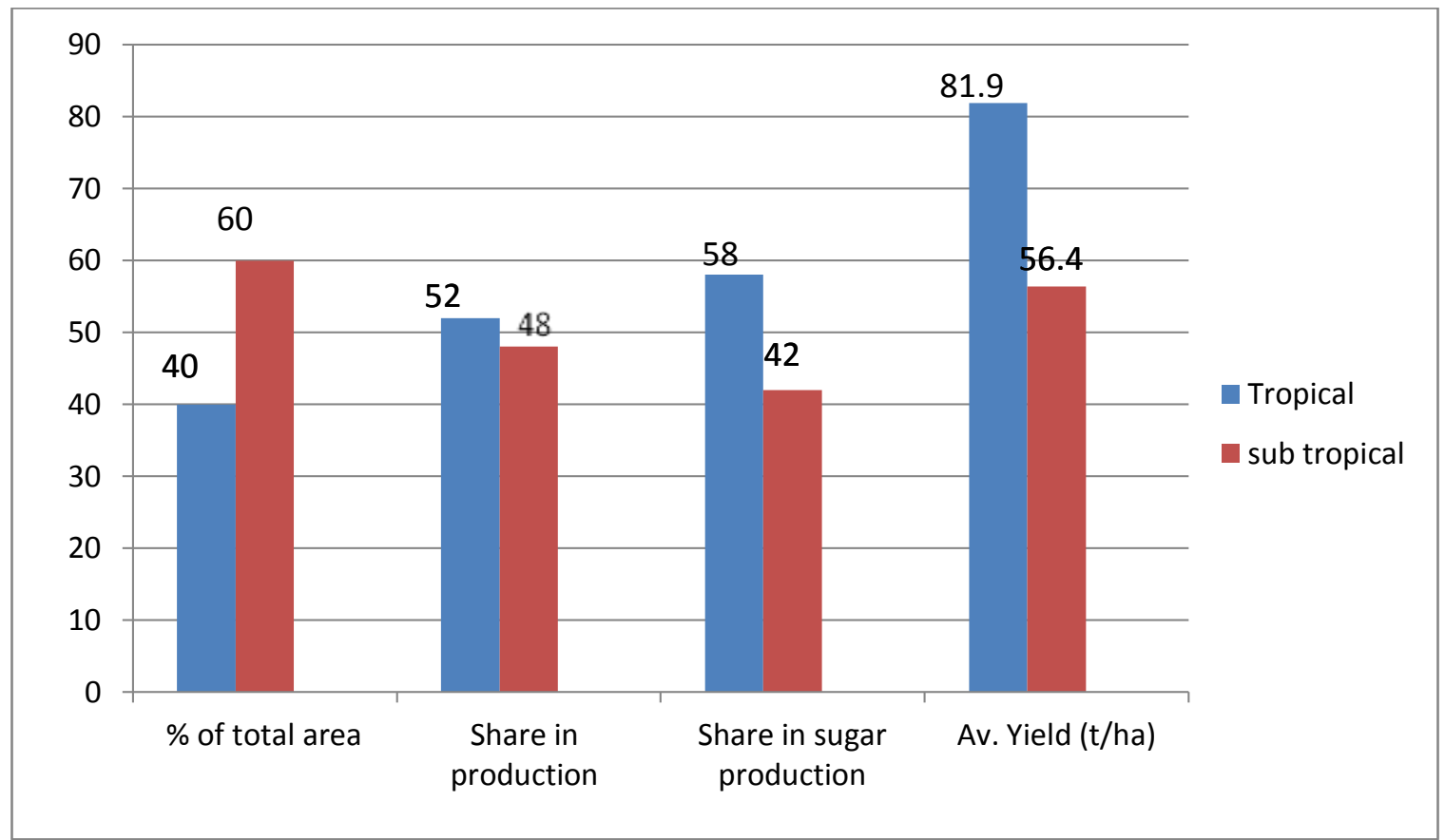

Fig 1:- Comprarision of tropical and subtropical region in India.

Sugarcane in India, is cultivated broadly with two distinct agro - climatic regions Known as tropical and subtropical regions. The tropical region comprising the states of Maharashtra, Tamil Nadu, Karnataka, Andhra Pradesh, Gujarat, Chhattisgarh, Orissa and Kerla accounts for $42.9 \%$ of the total area under sugarcane in the country. The subtropical region comprising the states of U.P., Bihar, Punjab, Haryana, Uttarakhand, M.P., Rajasthan, West Bengal, Jharkhand, Assam and other North and North- eastern states and accounts for 57.1 percent of total cane area in the country. The tropical region divided into two viz., coastal and peninsular zone. Similarly, sub tropical divided into North West - north coastal and north cost zone. In subtropical region U.P is the main cane growing state allocating about 2.2 million ha area $(43.7 \%)$ for cane cultivation followed by Maharashtra with about 0.98 million hectare $(19.6 \%)$ of total cane area in the country. Karnataka and Tamil Nadu are other major cane growing states in tropical belt accounting for 6 to $8 \%$ of the cane area followed by AP and Gujarat (3-4\%). In subtropical belt, after U.P. the Bihar, UttaraKhand, Haryana, Punjab and M.P are the important cane growing states in descending order, each accounting for about 1.5 to $5 \%$ of the cane area in the country. The area, production and yield levels of major cane growing states in the country are shown in Table (1). 


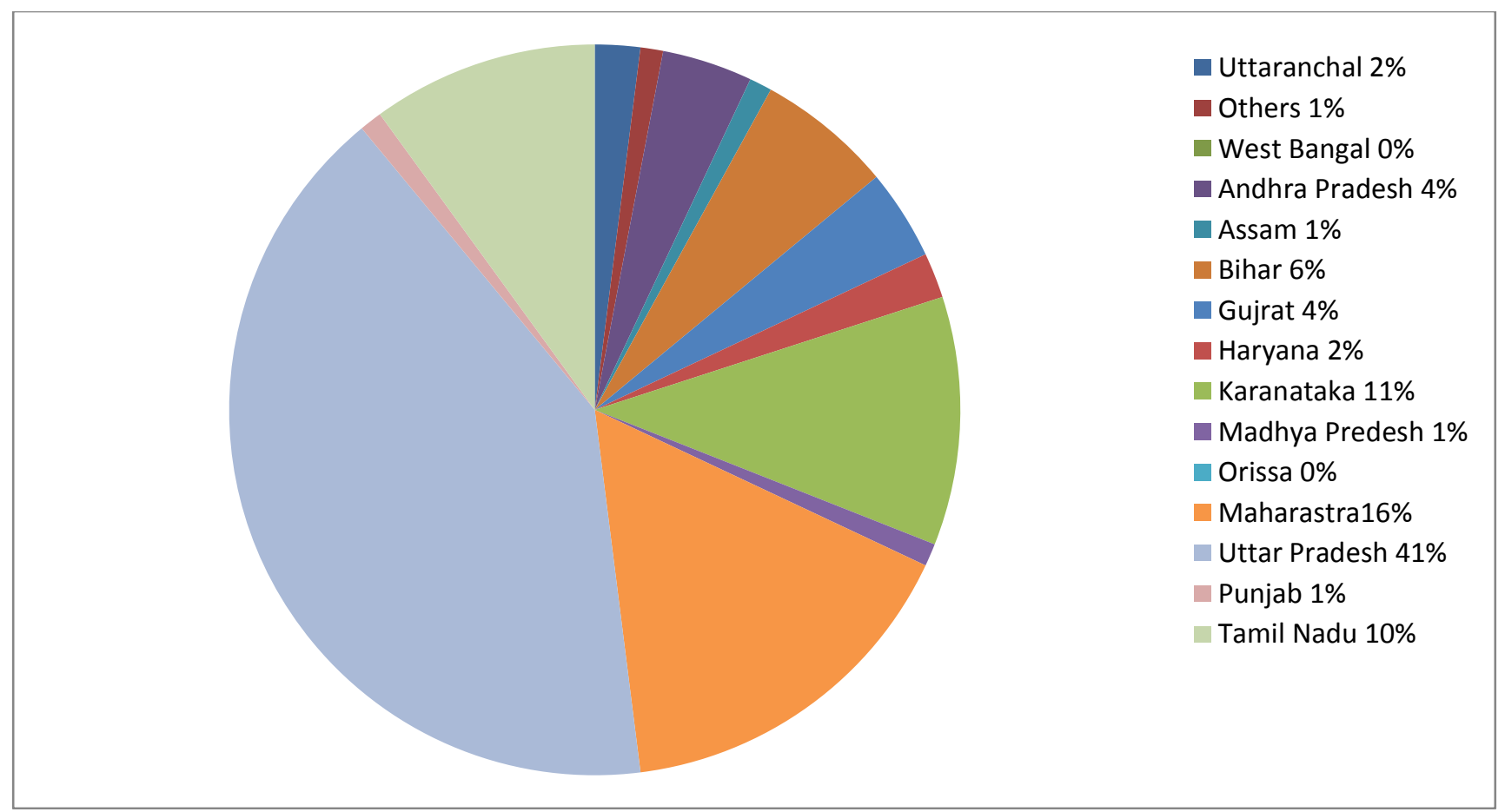

Fig. 2:-State wise distribution of additional output of sugarcane in India.

Table 1:-Top five states in sugarcane area, production and yield in 2016-17.

\begin{tabular}{|c|l|c|l|c|l|c|}
\hline Rank & \multicolumn{2}{|c|}{ Area wise } & \multicolumn{2}{c|}{ Production wise } & \multicolumn{2}{c|}{ Yield wise } \\
\hline & \multicolumn{1}{|c|}{ State } & (Lakh ha) & \multicolumn{2}{c|}{ State } & State & \multicolumn{1}{c|}{ (t/ha) } \\
\hline 1 & U. P. & 21.90 & U. P. & 133.70 & Tamil Nadu & 105.00 \\
\hline 2 & Maharashtra & 9.87 & Maharashtra & 75.09 & Maharashtra & 80.90 \\
\hline 3 & Karnataka & 4.00 & Karnataka & 34.20 & Karnataka & 90.30 \\
\hline 4 & Tamil Nadu & 2.63 & Tamil Nadu & 27.62 & U.P & 72.37 \\
\hline 5 & Bihar & 2.58 & Bihar & 14.24 & Bihar & 65.40 \\
\hline & & \multicolumn{4}{c|}{ Source: Cooperative Sugar (2016) } \\
\hline
\end{tabular}

Table 2:-Growing population and estimated sugar consumption in India upto 2050.

\begin{tabular}{|c|c|c|c|c|}
\hline Year & Population in millions & \multicolumn{3}{|c|}{ Sugar consumption (m. tons) } \\
\hline & & $\begin{array}{c}\text { @ 20kg per } \\
\text { capita }\end{array}$ & @ 30kg per capita & @ 40kg per capita \\
\hline 2010 & 1180 & 23.60 & 35.40 & 47.20 \\
\hline 2030 & 1470 & 29.40 & 44.10 & 58.82 \\
\hline 2050 & 1757 & 35.10 & 52.71 & 70.28 \\
\hline
\end{tabular}

Table 3:-Top five countries in sugarcane area, production and yield (2016) .

\begin{tabular}{|c|l|c|l|c|l|c|}
\hline Rank & \multicolumn{2}{|c|}{ Area wise } & \multicolumn{2}{c|}{ Production wise } & \multicolumn{2}{c|}{ Yield wise } \\
\hline & Country & Area(m ha) & Country & $(\mathbf{m t})$ & Country & $($ t/ha) \\
\hline 1 & Brazil & 10.44 & Brazil & 737.16 & Peru & 133.72 \\
\hline 2 & India & 5.10 & India & 362.33 & Ethiopia & 119.57 \\
\hline 3 & China & 1.75 & China & 126.00 & Egypt & 115.33 \\
\hline 4 & Thailand & 1.35 & Thailand & 104.00 & Senegal & 114.10 \\
\hline 5 & Pakistan & 1.17 & Pakistan & 67.46 & $\begin{array}{l}\text { Malavi } \\
\text { Senegal }\end{array}$ & 107.41 \\
\hline
\end{tabular}


Table 4:-Trends in sugarcane area, production, productivity and sugar recovery of U.P. (2006 to 2016).

\begin{tabular}{|l|c|c|c|c|c|}
\hline Year & $\begin{array}{c}\text { Sugarcane area } \\
\text { (mha) }\end{array}$ & $\begin{array}{c}\text { Sugarcane } \\
\text { Production }(\mathbf{m t})\end{array}$ & $\begin{array}{c}\text { Cane } \\
\text { productivity } \\
(\mathbf{t} / \mathbf{h a})\end{array}$ & $\begin{array}{c}\text { Sugar } \\
\text { production } \\
(\mathbf{m t})\end{array}$ & $\begin{array}{c}\text { Sugar } \\
\text { recovery }(\%)\end{array}$ \\
\hline $2006-07$ & 2.25 & 133.95 & 58.20 & 8.48 & 9.47 \\
\hline $2007-08$ & 2.18 & 124.67 & 59.60 & 7.32 & 9.79 \\
\hline $2008-09$ & 2.08 & 109.05 & 57.20 & 4.06 & 8.94 \\
\hline $2009-2010$ & 1.98 & 117.14 & 52.30 & 5.18 & 9.13 \\
\hline $2010-2011$ & 2.13 & 120.55 & 59.30 & 5.89 & 9.14 \\
\hline $2011-2012$ & 2.16 & 128.82 & 56.70 & 6.97 & 9.07 \\
\hline $2012-2013$ & 2.11 & 132.43 & 59.60 & 7.49 & 9.18 \\
\hline $2013-2014$ & 2.23 & 134.69 & 59.90 & 6.49 & 9.25 \\
\hline $2014-2015$ & 2.14 & 133.06 & 60.50 & 7.10 & 9.54 \\
\hline $2015-2016$ & 2.18 & 145.39 & 66.46 & 6.84 & 10.61 \\
\hline $2016-2017$ & 2.19 & 133.70 & 72.37 & 8.75 & 10.61 \\
\hline
\end{tabular}

Table 5:-World sugar balance (1000. Tonnes, raw value) during 2015-16.

\begin{tabular}{|l|c|c|c|c|c|c|}
\hline \multicolumn{1}{|c|}{ Country } & $\begin{array}{c}\text { Opening } \\
\text { stocks }\end{array}$ & Production & imports & Consumption & Export & $\begin{array}{c}\text { Ending } \\
\text { stocks }\end{array}$ \\
\hline India & 9120 & 25100 & - & 25600 & 1500 & 7080 \\
\hline Brazil & 1083 & 35590 & - & 12625 & 22965 & 1083 \\
\hline Thailand & 4266 & 11400 & - & 3020 & 8900 & 3746 \\
\hline Australia & 1929 & 4700 & 120 & 1005 & 3815 & 1929 \\
\hline
\end{tabular}

Table 6:-Total installed sugar factories in major states of India (2015-16).

\begin{tabular}{|l|c|c|c|c|}
\hline \multicolumn{1}{|c|}{ State } & Private & Public & Co -op & Total \\
\hline Bihar & 13.00 & 15.00 & - & 29.00 \\
\hline U.P. & 116.00 & 14.00 & 28.00 & 158.00 \\
\hline Uttarakhand & 4.00 & 2.00 & 4.00 & 10.00 \\
\hline Punjab & 8.00 & - & 16.00 & 24.00 \\
\hline Haryana & 3.00 & - & 13.00 & 16.00 \\
\hline A.P. & 20.00 & 1.00 & 12.00 & 33.00 \\
\hline Tamilnadu & 27.00 & 3.00 & 16.00 & 46.00 \\
\hline Maharashtra & 80.00 & - & 169.00 & 249.00 \\
\hline Karnataka & 48.00 & 3.00 & 25.00 & 76.00 \\
\hline Gujarat & 5.00 & - & 22.00 & 27.00 \\
\hline West Bengal & 2.00 & 1.00 & - & 3.00 \\
\hline Total & 360.00 & 42.00 & 325.00 & 727.00 \\
\hline (Durg
\end{tabular}

(During 2015-16, No of factories in operation in U.P., Bihar, Uttarakhand and West Bengal were 116, 11, 8 and 4 respectively).

Sugar Associations in India (5):-

1. ISMA (Indian Sugarmill Association)

2. NFCSF (National Federation of Co- operative Sugar Factories Ltd.)

3. AIDA (All India Distillers Association )

4. STAI (The Sugar Technologist Association of India)

5. ISEC (Indian Sugar Exim Corporation Ltd.)

\section{Regional and State Associations (25):-}

1. Private Sector -13

2. Co - operative sector -10

3. Public sector -2 


\section{Sugar Institutes in India (2):-}

1. NSI, Kanpur, U.P.

2. VSI, Pune, Maharashtra

\section{Regional Technologists Association (6+1):-}

1. SISSTA, Chennai

2. DSTA (Deccan Sugar Technologist Associate, India)

3. VAMNI COM (Vaikunth Mehta National institute of cooperative Management, Pune)

4. ASTI, IISR, Lucknow

5. AICRP (S), IISR, Lucknow

6. SSRP (Society for Sugar Research \& Promotion)

7. NISSTA - (North Indian Sugarcane and Sugar Technologists Association)

\section{Financial Institutes:-}

1. NCDC (National Co operative Development of New Delhi Corporation, New Delhi)

2. IFCI (Industrial Finance Corporation of India, New Delhi)

3. IDBI (Industrial Development of India, Mumbai)

4. ICICI (The Industrial Credit \& investment Corporation of India Ltd., Mumbai)

5. $\quad$ RBI (Reserve Bank of India, Mumbai)

\section{Price policy recommendation for sugarcane:-}

The commission recommended a fair remunerative Price (FRP) for sugarcane to be Rs 230/qt. At $9.5 \%$ recovery level for 2016-17 sugar season. With every increase in recovery by $0.1 \%$ point, the FRP will increase by 2.42 Rs. Per quintal. All India average recovery rate being $10.25 \%$, the FRP recommended would work out to Rs 248 / qt.

\section{Non - price recommendation:-}

Water productivity analysis show that Bihar consumes just 822 lit. of water to produce one kilogram of sugar compared to 2014 lit in Maharashtra so in Maharashtra drip irrigation is very essential.

\section{Limitations / factors for sugarcane yield gaps and sugar production in India:-}

Number of constraints in sugarcane production influences its successful cultivation. These are resource, site specific, technology, climate, socio - economic and environmental constraints which hamper the cane productivity and sugar production to rise above a certain level. These constraints in two major climate zones: Tropical and subtropical zones are as follows:

1. Environmental constraints

2. Biotic and abiotic constraints

3. Small size of the sugar cane form

4. Varietal constraints

5. Poor ratoon crop stands

6. Delayed planting

7. Socio - economic constraints

8. Marketing and post - harvest constraints

9. Cyclicality in cane production

10. Declining soil health and depleting water resources.

11. High cost of sugarcane production.

1. Environmental constraints:-

Under subtropical condition narrow time span is available during both autumn (October - November) and spring (February - March) for germination to take place as both the seasons are followed by extremes of low and high temperature, respectively. Under intensive cropping, sugarcane is being grown on unfavorable soil conditions such as saline - alkali, water logged and drought affected soils leading to poor yield.

\section{Biotic and abiotic constraints:-}

The sugarcane crop in subtropical region subjected to biotic stresses viz., red rot, smut, wilt, grassy shoot; ratoon stunting and leaf scald diseases. The main insect - pests like root borer, top borer, stalk borer, pyrilla and scale insect are the major constraints. In tropical India, the aforesaid diseases in addition to pine apple set rot 
and the yellow leaf disease are the limiting factors in cane production. The major abiotic stresses include limited availability to suitable soil, irrigation water and uncongenial temperature for high sucrose formation.

3. Small size of the sugar cane form:-

There are 6 millions cane growers in India having the cane farm - size of 0.77 ha on average (table - 5). About $60 \%$ cane holdings are in marginal category having the size of the cane farm less than 0.35 ha. Among sub tropical states, U.P. has about 3 million cane growers and the size of the cane farm is 0.72 ha and it is larger than Maharashtra and other tropical southern states. Due to very high with growing labour scarcity, the profit margin as percentage of gross returns has decreased over the years.

Table 7:-Total cane holdings and average size of sugarcane farms in India.

\begin{tabular}{|l|c|c|c|c|c|c|c|}
\hline \multirow{3}{*}{ State } & \multicolumn{3}{|c|}{ Holdings } & \multicolumn{3}{c|}{ Average cane area per farm (ha) } \\
\cline { 2 - 8 } & $\begin{array}{c}\text { Total } \\
\text { (million) }\end{array}$ & $\begin{array}{c}\text { Share } \\
\mathbf{\%}\end{array}$ & $\begin{array}{c}\mathbf{\%} \text { to total } \\
\text { holdings }\end{array}$ & $\begin{array}{c}\text { Marginal } \\
(<\mathbf{1 h a})\end{array}$ & $\begin{array}{c}\text { Small } \\
(\mathbf{1 - 2} \text { ha) }\end{array}$ & $\begin{array}{c}\text { Large } \\
(>\mathbf{1 0} \text { ha) }\end{array}$ & Overall \\
\hline Maharashtra & 1.01 & 16.90 & 8.38 & 0.33 & 0.66 & 2.49 & 0.62 \\
\hline Uttar Pradesh & 3.03 & 50.60 & 14.00 & 0.34 & 0.81 & 7.40 & 0.72 \\
\hline All India & 5.99 & 100.00 & 5.07 & 0.36 & 0.77 & 3.53 & 0.77 \\
\hline
\end{tabular}

4. Varietal constraints:-

Despite the fact that rich diversity of sugarcane germination. Out of 2070 clones available at species level, hardly 50 have been utilized in the breeding programme. It is imperative to tap the huge available genetic potential to break both sugar and yield barriers. There is need to quick replacement of old cane varieties. Inadequate healthy seed supply of newly released varieties is yet another constraint.

5. Delayed planting and poor ratoon crop stands:-

In north western zone of subtropical India and western part of U.P. wheat sugarcane (Plant) - ratoon - wheat is the prevalent sugarcane based cropping system. In this region delayed planting after April and upto may produces lesser tillers due to very high temperature, hot desiccating wind, over matured seed cane and rapid loss of moisture from setts and soil adversely affect the bud sprouting when sugarcane is planted after wheat harvest.Around $40 \%$ area of total cane produced is through ratoon crop but yield is lower than plant crop. The stubble sprouting during winter give rise the ratoon have poor stand harvested in December and January. Farmer's assume ratoon as a free crop which bring the yield down.

6. Socio - economic constraints:-

Poor economic condition of farmers and lack of infra structure and inadequate extension strategies result into low consumption of fertilizers, plant protection and other inputs required in time.

7. Marketing post harvest constraints:-

Bulkiness, non- storability, post harvest deterioration, restricted buyers, government high regulations are the limitations in sugarcane marketing which becomes entirely different from that of other crops.

8. High cost of sugarcane production and cyclicality in cane production:-

Cost of production mainly due to high productivity per unit area are possible only through mechanization and adoption of cost effective technological intervention cane agriculture.Cyclicality in cane production has been the bane of Indian sugar sector. The Indian sugar industry lacks the flexibility of the Brazilian sugar industry.

9. Declining soil health and depleting water resources:-

The soil carbon content and other nutrients going down at an alarming rate in many regions.Practice of green manuring, intercropping, use of organic manures, trash mulching, INM etc.May check the declination in soil health.

Continued Monocropping, furrow/ flood irrigation and changes in precipitation patterns, the crop faces water deficit. The total consumptive use of water varies from 200 to $250 \mathrm{~cm}$ for sugarcane during crop period. A part of this is meet through rainfall and the remain through irrigation. Adoption to micro irrigation like drip and water management technologies like water harvesting etc. are the need of the day, since water is becoming a limited 
resource. Bangar and Sharma 1997 and Yadavet al., 1986 also reported 30\% economy in irrigation water in sugarcane through trash mulching.

\section{Strategies to enhance sugarcane productivity and profitability:-}

The ways and mean for achieving cane yield beyond 100 t/ha would be as follows:

1. Revival of the seed cane programme

2. Ensuring availability of quality seed cane

3. Varietal planning and replacement of old and rejected varieties

4. Improving productivity of ratoon canes

5. Reducing cost of cane cultivation by improving (1) Integrated nutrient management technology (2) Water use efficiency through micro- irrigation 3. Land use efficiency through companion cropping (4) Insect pests and diseases control by integrated pest management (IPM) and integrated disease management (IDM) technologies (5) Mechanized sugarcane farming.

6. Encouraging intercropping in sugarcane

\section{Sugar production vision 2030:-}

With for achieving high cane productivity along with sustainability and contributing to the nation's food and energy needs, the industry explores all available option to realize this vision. The population in the present is set to reach 1.5 billion by 2030 at the present compound growth rate of $1.6 \%$ per annum. The projected requirement of sugar for domestic consumption in 2030 is $36 \mathrm{mt}$ which is about $50 \%$ higher than the present production. To achieve this target, the sugarcane production should be about $500 \mathrm{mt}$ from the current $350 \mathrm{mt}$ for which the production has increased by 7-8 $\mathrm{mt}$ annually. The increased production has to be achieved from the existing cane area through improved productivity (> $100 \mathrm{t} / \mathrm{ha}$ ) and sugar recovery (>11\%). Since, further expansion in cane area is not feasible. The energy demand in India is estimated to grow by $200 \%$ or more by 2030 (Nair, 2010). Nambiar (1995) and Swaroop (1998) also predicted that the soil organic carbon was increased with the application of NPK+ FYM continuously for 20 years compared to initial status of soil.

\section{Conclusion:-}

Soils of the intensively cultivated areas and climatic conditions of northern region of India sugarcane and sugar production needs more special attention. Maintaining soil health, rising water table, mechanization in cultivation, INM IPM and IDM, better ratoon management, intercropping and improved agronomic practices with improved varieties etc are of great importance to achieve the target getting more income.

\section{References:-}

1. Bangar, K.S. and Sharma, S. R. 1997. Role of organic farming in improving sugarcane and sugar productivity. Indian J. of Sug. Tech. 12 (1): 59-66

2. Nair, K.V. 2010. The challenges and opportunities in sugarcane agriculture. Souvenir, STAI. PP. 117-135.

3. Nambiar, K.K. M. 1995. In : soil fertility and crop productivity under long term fertilizer use in India. ICAR, New Delhi.

4. Swaroop, A. 1988. In long term soil fertility management through integrated plant nutrient supply. AICRP on long term fertilizer experiments IISS, Bhopal: 54-68.

5. Yadav, R. L., Prasad, S. R. and Singh K. 1986. Effect of potassium and trash mulch on yield and quality of sugarcane under limited water supply. J. potassium. Res. 2 (4): 136-139. 